\title{
Kristal Hemoglobin Pada Bercak Darah yang Dipaparkan Sodium Hipoklorit (NaOCl) Menggunakan Tes Teichmann Dan Tes Takayama
}

\author{
Romdonah, ${ }^{1}$ Radha Zatti Rahmi, ${ }^{1}$ Mohammad Tegar Indrayana, ${ }^{2}$ Fridayenti, ${ }^{3}$ Enikarmila Asni ${ }^{4 *}$
}

\begin{abstract}
Bloodstains is an important body fluids as evidence, because the blood has hemoglobin structure consisting of heme and polypeptides. Perpetrators will attempt to clean the bloodstain that found at the crime scene by using cleaning agents and chemicals. Sodium hypochlorite is a chemical that found in cleaning fluids and bleach. This study aims to know the effects of sodium hypochlorite to bloodstain and confirmatory test. Bloodstain on the objeck glasses and the fabrics exposed by sodium hypochlorite concentration 5,25\% and $0,15 \%$, and examined with Teichmann's test and Takayama's test, and seen under microscope. In this study, show no crystal hemoglobin of the bloodstain on the objeck glasses and fabrics exposed by sodium hypochlorite concentration $5.25 \%$ and concentration $0,15 \%$. This might caused by sodium hypochlorite destructed structure of heme, so there were no reaction between heme, sodium chloride and acetat glacial acids on Teichmann's test and no reaction between heme and Takayama's reagen on Takayama's test. The conclusions of this study, crystal hemoglobin were not found on bloodstain exposed by sodium hypochloryte using Teichmann's test and Takayama's test.
\end{abstract}

Keywords: Bloodstain, crystals hemoglobin, sodium hypochlorite, Teichmann's test, Takayama's test

Kejahatan merupakan tindakan atau kelalaian yang dilarang oleh hukum, yang dapat dihukum dengan pidana penjara atau denda. ${ }^{1}$ Barang bukti yang dapat ditemukan oleh penyidik di tempat kejadian perkara (TKP) dari setiap tindak kejahatan salah satunya adalah cairan tubuh. Darah merupakan cairan tubuh yang penting sebagai barang bukti, karena darah memiliki komponen spesifik yaitu rantai hemoglobin yang terdiri dari heme yang merupakan besi dan globin yang merupakan rantai polipeptida. Bercak darah merupakan darah yang telah mengering dan sering ditemukan sebagai barang bukti yang dapat menempel pada pakaian, lantai, kursi, meja serta senjata. ${ }^{2}$

\footnotetext{
* Penulis untuk korespondensi : Bagian Biokimia FK Unri, Jl. Diponegoro no 1 Pekanbaru, email karmila.93@gmail.com

1 Fakultas Kedokteran Universitas Riau

2 KJF Forensik dan Medikolegal FK Unri

KJF Patologi Klinik FK Unri

KJF Biokimia FK Unri
}

Objek tempat melekatnya bercak darah yang dapat ditemukan di TKP adalah kaca dankain. Objek inilah yang akan dilakukan pemeriksaan darah forensik. ${ }^{3}$ Pemeriksaan darah dan bercak darah di laboratorium forensik dapat dilakukan dengan beberapa cara diantaranya tes visualisasi, tes skrining presumptive, tes konfirmasi, pemeriksaan imunologi dan tes pemeriksaan DNA spesifik. Tes konfirmasi dilakukan untuk mengidentifikasi bercak darah pada barang bukti. Tes konfirmasi yang sering digunakan adalah tes Teichmann dan tes Takayama. ${ }^{3,4}$

Pelaku kejahatan akan berusaha untuk menghilangkan bercak darah yang melekat pada barang bukti dengan menggunakan air dan zat kimia. ${ }^{2,4,5}$ Zat kimia yang murah dan mudah didapatkan masyarakat adalah produk pemutih pakaian. ${ }^{6}$ Sodium hipoklorit merupakan bahan kimia yang terdapat di dalam larutan pembersih dan pemutih pakaian. Sodium hipoklorit bekerja dengan cara merusak membran sel dan menyebabkan hidrolisis dan degradasi asam amino. ${ }^{7,8}$ 
Belum adanya penelitian yang menjelaskan mengenai gambaran kristal hemoglobin pada bercak darah yang dipaparkan dengan sodium hipoklorit baik pada kaca objek maupun kain, menyebabkan peneliti ingin melakukan penelitian mengenai gambaran kristal hemoglobin dari bercak darah pada kaca objek dan kain yang dipaparkan dengan sodium hipoklorit yang tidak tampak secara visual menggunakan Tes Takayama.

\section{METODE}

Penelitian ini merupakan penelitian eksperimental dengan tiga kali pengulangan (triplo) dalam dua sesi yang dilakukan untuk mengidentifikasi kristal hemoglobin dari bercak darah yang menempel pada kaca objek dan kain yang sebelumnya telah dipaparkan dengan sodium hipoklorit. Penelitian ini dilakukan di Laboratorium Biokimia Fakultas Kedokteran Universitas Riau, pada bulan Juni sampai Oktober 2016.

Bahan-bahan yang digunakan dalam penelitian ini adalah darah, $\mathrm{NaCl}$, asam asetat glasial, aquadest, reagen Takayama (mengandung larutan glukosa standar $100 \mathrm{~g} / 100 \mathrm{ml}$, sodium hidroksida $10 \%$, pyridine dan air yang telah terdistilasi), dan sodium hipoklorit.

Alat-alat yang diperlukan dalam penelitian ini adalah benang, holder kayu, kaca objek/ slide, kaca penutup (deck glass), kain, lampu spiritus, mikro pipet, mikroskop, dan wadah bersih.

\section{Pembuatan slide bercakdarah}

Pembuatan slide bercak darah diawali dengan persiapan kaca objek dan kain. Kaca objek dibersihkan dari kotoran yang melekat dengan dibakar di atas api bunsen, sedangkan kain yang akan dilakukan untuk penelitian, sebelumnya diberi tanda dengan jahitan melingkar dengan diameter 1,5 $\mathrm{cm}$. Kaca objek dan kain ditetesi dengan darah yang berasal dari darah vena sukarelawan yang telah dimasukkan kedalam tabung EDTA yang bervolume $3 \mathrm{ml}$ sebanyak $0,1 \mathrm{ml}$. Kaca objek dan kain bercak darah kemudian didiamkan dan dibiarkan mengering pada suhu ruangan $\left(25^{\circ} \mathrm{C}\right)$ selama lebih kurang 1 jam. Slide bercak darah dan kain bercak darah dibuat dengan 3 kali pengulangan dan di lakukan dalam 2 sesi sehingga jumlah seluruh slide bercak darah sebanyak 72 slide. Pemaparan slide bercak darah dilakukan dengan cara sebagai berikut, slide bercak darah direndam menggunakan sodium hipoklorit hingga bersih, kemudian dilakukan Tes Teichmann dan Tes Takayama. Kain bercak darah direndam menggunakan sodium hipoklorit hingga bersih, kemudian tepat pada daerah yang telah ditandai dengan jahitan diteteskan $2 \mathrm{ml} \mathrm{NaCl}$. Larutan yang terbentuk antara bercak darah dan $\mathrm{NaCl}$ disentrifugasi dan ambil bagian pellet, kemudian letakkan diatas kaca objek yang telah dibersihkan dan biarkan mongering dalam suhu ruangan $\left(25^{\circ} \mathrm{C}\right)$ selama lebih kurang 1 jam, selanjutnya dilakukan Tes Teichmann dan Tes Takayama. Slide bercak darah yang lain direndam selama 15 menit dalam larutan sodium hipoklorit sebanyak $30 \mathrm{ml}$ yang dicampur dengan $1 \mathrm{~L}$ air, kemudian dilakukan tes Teichmann dan tes Takayama. Kain bercak darah yang lain direndam selama 15 menit dalam larutan sodium hipoklorit sebanyak $30 \mathrm{ml}$ yang dicampur dengan $1 \mathrm{~L}$ air, kemudian tepat pada daerah yang telah ditandai dengan jahitan diteteskan $2 \mathrm{ml} \mathrm{NaCl}$. Larutan yang terbentuk antara bercak darah dan $\mathrm{NaCl}$ disentrifugasi dan ambil bagian pellet, kemudian letakkan diatas kaca objek yang telah dibersihkan dan biarkan mongering dalam suhu ruangan $\left(25^{\circ} \mathrm{C}\right)$ selama lebih kurang 1 jam, selanjutnya dilakukan Tes Teichmann dan Tes Takayama.

\section{Pemeriksaan Tes Teichmann}

Prosedur pelaksanaan Tes Teichmann diawali dengan menempatkan sampel yang akan diuji pada kaca objek, kemudian diteteskan dengan satu tetes sodium klorida dan satu tetes asam asetat glasial, tutup dengan kaca penutup (deck glass). Panaskan secara perlahan-lahan pada suhu kira-kira $65^{\circ} \mathrm{C}$ selama sepuluh sampai dua puluh detik, kemudian biarkan sampai dingin untuk dilakukan pemeriksaan dibawah mikroskop dengan pembesaran 40-100 kali.Sasaran yang dilihat adalah tampaknya kristal hemin $\mathrm{HCl}$ yang berbentuk belah ketupat berwarna coklat.

\section{Pemeriksaan Tes Takayama}

Prosedur pelaksanaan Tes Takayama dilakukan dengan menempatkan objek yang akan diperiksa 
pada kaca objek. Kaca objek yang telah berisi objek yang akan diperiksa kemudian ditutup dengan kaca penutup slide (deck glass). Reagen Takayama diteteskan pada kaca objek sebanyak 1 tetes dan dibiarkan mengalir hingga melalui kaca penutup slide. Kaca objek dipanaskan pada suhu $65^{\circ} \mathrm{C}(15$ $\mathrm{cm}$ diatas api bunsen) selama 10 hingga 20 detik. Kaca objek yang telah dipanaskan dibiarkan sampai dingin untuk dilakukan pemeriksaan di bawah mikroskop pada pembesaran 40-100 kali. Hasil positif dinyatakan dengan ditemukannya kristal berbentuk jarum yang berwarna merah muda.

\section{HASIL}

Pemeriksaan tes Teichmann dan tes Takayama pada bercak darah dengan jumlah 72 slide pemeriksaan terdiri dari 12 slide kontrol positif pada tes Teichmann, 12 slide kontrol positif pada tes Takayama, 24 slide dengan perlakuan kemudian dilakukan tes Teichmann, dan 24 slide dengan perlakuan kemudian dilakuakn tes Takayama. 12 slide kontrol pada tes Teichmann menunjukkan hasil positif, 12 slide kontrol pada tes Takayama menunjukkan hasil positif, 24 slide dengan perlakuan yang dilakukan pemeriksaan tes Teichmann menunjukkan hasil negatif dan 24 slide dengan perlakuan yang dilakukan pemeriksaan tes Takayama menunjukkan hasil negatif seperti pada Tabel 1, Tabel 2 dan Tabel 3.

Tabel 1. Slide kontrol pemeriksaan tes Teichmann dan tes Takayama

\begin{tabular}{ccccc}
\hline \multirow{2}{*}{ Sampel } & \multicolumn{4}{c}{ Kristal hemoglobin } \\
\cline { 2 - 5 } & \multicolumn{2}{c}{ Tes Teichmann } & \multicolumn{2}{c}{ Tes Takayama } \\
\cline { 2 - 5 } & Kaca objek & Kain & Kaca objek & Kain \\
\hline A.1 & Positif & Positif & Positif & Positif \\
A.2 & Positif & Positif & Positif & Positif \\
A.3 & Positif & Positif & Positif & Positif \\
B.1 & Positif & Positif & Positif & Positif \\
B.2 & Positif & Positif & Positif & Positif \\
B.3 & Positif & Positif & Positif & Positif \\
\hline
\end{tabular}

Keterangan:

A.1 : Sesi 1, Pengulangan 1

A.2 : Sesi 1, Pengulangan 2

A.3 : Sesi 1, Pengulangan 3

B.1 : Sesi 2, Pengulangan 1

B.2 : Sesi 2, Pengulangan 2

B.3 : Sesi 2, Pengulangan 3

Gambaran kristal hemoglobin dengan menggunakan tes Teichmann dapat dilihat pada Gambar 1 dan Gambar 2 dengan pembesaran 400.
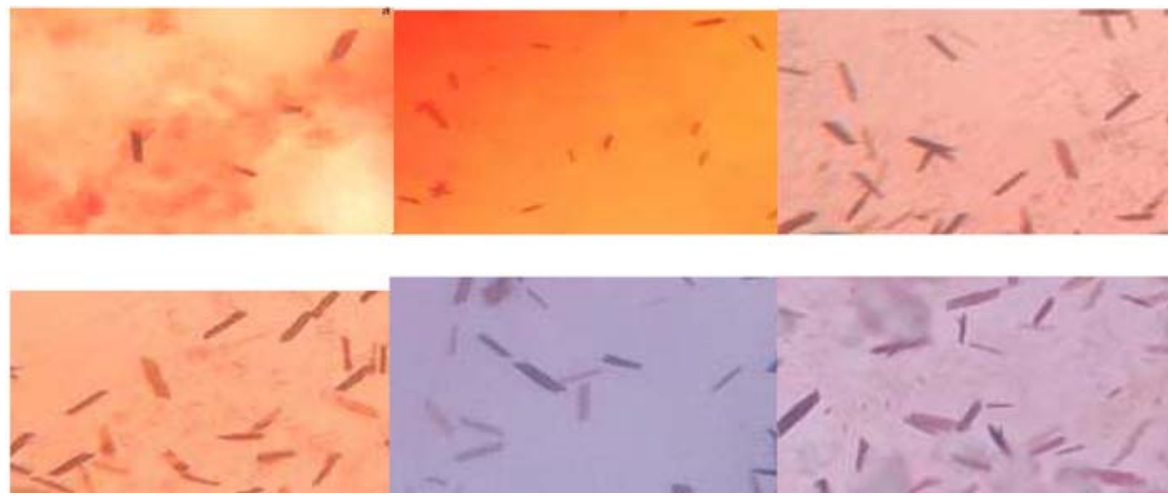

Gambar 1. Kristal hemoglobin positif pada kaca objek 
JIK, Jilid 11, Nomor 1, Maret 2017, Hal. 47-53
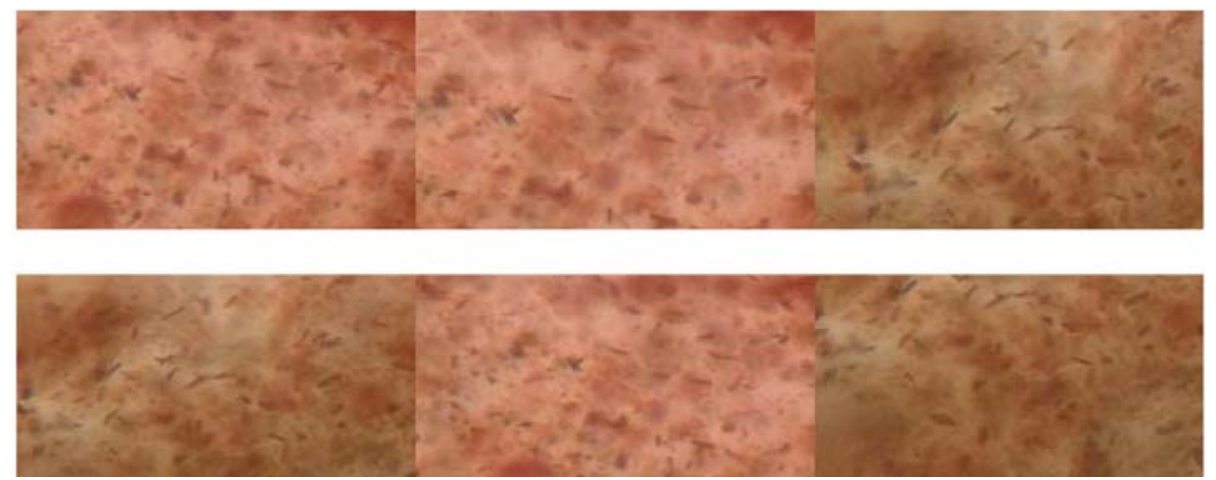

Gambar 2. Kristal hemoglobin positif pada kain

Gambaran kristal hemoglobin pada bercak darah dengan menggunakan tes Takayama dapat dilihat pada Gambar 3 dan Gambar 4.
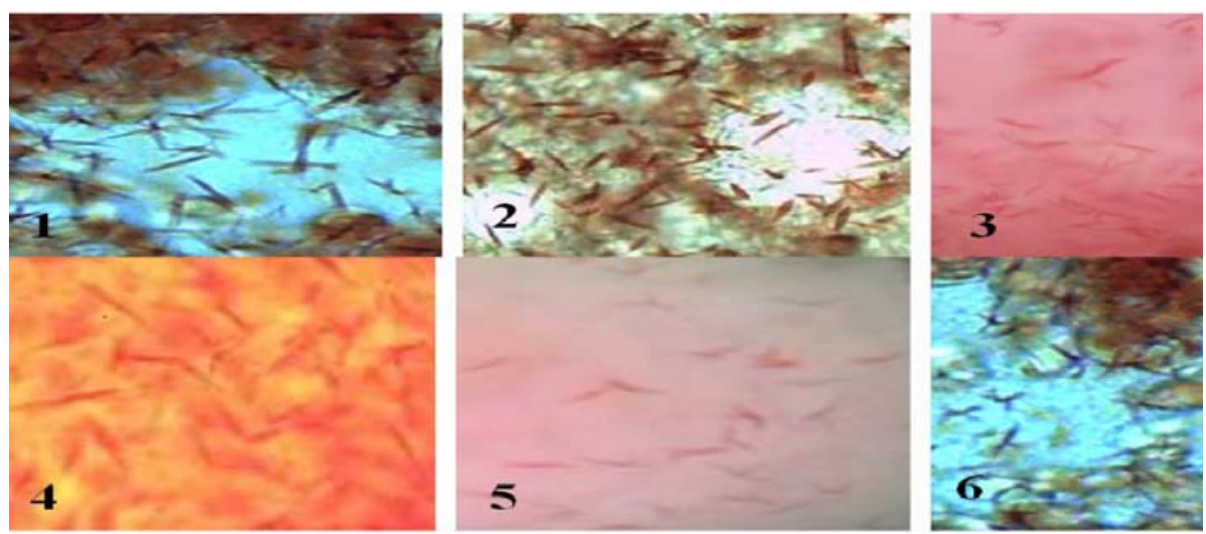

Gambar 3. Kristal hemoglobin positif pada kaca objek
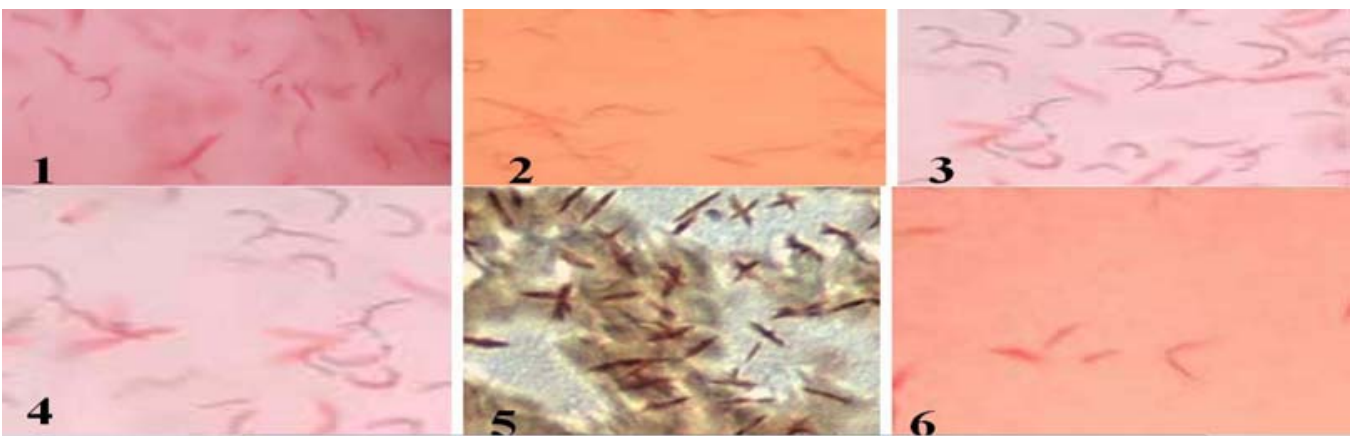

Gambar 4. Kristal hemoglobin positif pada kain 
Tabel 2. Hasil pemeriksaan tes Teichmann

\begin{tabular}{ccccc}
\hline & \multicolumn{4}{c}{ Kristal hemoglobin } \\
\cline { 2 - 4 } Sampel & \multicolumn{2}{c}{ Tes Teichmann } & \multicolumn{2}{c}{ Tes Takayama } \\
\cline { 2 - 4 } & Kaca objek & Kain & Kaca objek & Kain \\
\hline A.1 & Positif & Positif & Positif & Positif \\
A.2 & Positif & Positif & Positif & Positif \\
A.3 & Positif & Positif & Positif & Positif \\
B.1 & Positif & Positif & Positif & Positif \\
B.2 & Positif & Positif & Positif & Positif \\
B.3 & Positif & Positif & Positif & Positif \\
\hline
\end{tabular}

Tabel 3. Hasil pemeriksaan tes Takayama

\begin{tabular}{|c|c|c|c|c|}
\hline \multicolumn{5}{|c|}{ Kristal hemoglobin } \\
\hline \multirow[t]{2}{*}{ Sampel } & \multicolumn{2}{|c|}{ Kaca objek } & \multicolumn{2}{|c|}{ Kain } \\
\hline & $5,25 \%$ & $0,15 \%$ & $5,25 \%$ & $0,15 \%$ \\
\hline A.1 & Negatif & Negatif & Negatif & Negatif \\
\hline A. 2 & Negatif & Negatif & Negatif & Negatif \\
\hline A. 3 & Negatif & Negatif & Negatif & Negatif \\
\hline B.1 & Negatif & Negatif & Negatif & Negatif \\
\hline B. 2 & Negatif & Negatif & Negatif & Negatif \\
\hline B. 3 & Negatif & Negatif & Negatif & Negatif \\
\hline
\end{tabular}

Keterangan:

$\begin{array}{ll}\text { A.1 } & \text { : Sesi 1, Pengulangan } 1 \\ \text { A.2 } & \text { : Sesi 1, Pengulangan } 2 \\ \text { A.3 } & \text { : Sesi 1, Pengulangan } 3 \\ \text { B.1 } & \text { : Sesi 2, Pengulangan } 1 \\ \text { B.2 } & \text { : Sesi 2, Pengulangan } 2 \\ \text { B.3 } & \text { : Sesi 2, Pengulangan } 3\end{array}$

Hasil pemeriksaan bercak darah pada kaca objek dan kain yang terpapar larutan sodium hipoklorit konsentrasi $5,25 \%$ dan $0,15 \%$ dengan pemeriksaan konfirmasi menggunakan tes Teichmann dan tes Takayama adalah tidak ditemukan kristal hemoglobin dari bercak darah yang terdapat pada kaca objek dan kain (kristal hemoglobin negatif).

\section{PEMBAHASAN}

Tes Teichmann merupakan pemeriksaan darah forensik yang bekerja pada gugus ferriprotoporfirin yang terdapat pada heme, saat darah dan bercak darah diteteskan dengan sodium klorida dan asam asetat glasial, maka akan terbentuk kristal ferriprotoporphyrine chloride seperti pada Gambar 5. ${ }^{9}$

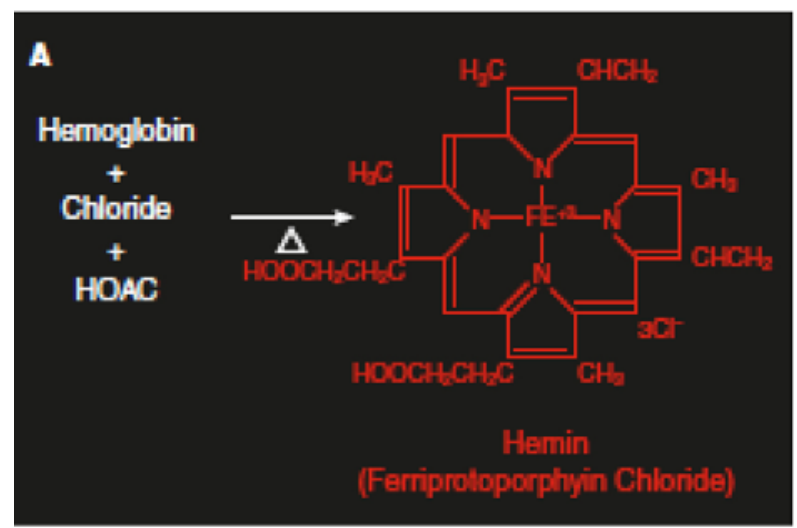

Gambar 5. Reaksi Teichmann ${ }^{9}$

Tes Takayama merupakan tes konfirmasi untuk pemeriksaan bercak darah menggunakan larutan piridin, glukosa, dan sodium hidroksida $(\mathrm{NaOH})$ $10 \%$ sebagai reagen. Reagen tersebut bereaksi dengan heme dan menghasilkan kristal hemokromogen (pyridine ferroprotoporphyrin) berbentuk jarum dan berwarna merah jambu yang tampak di bawah mikroskop. ${ }^{10}$ Pembentukan kristal hemokromogen terjadi karena oksidasi elektron $\mathrm{Fe}$ yang berikatan dengan piridin $\left(\mathrm{C}_{5} \mathrm{H}_{5} \mathrm{~N}\right)$, glukosa $\left(\mathrm{C}_{6} \mathrm{H}_{12} \mathrm{O}_{6}\right)$ dan $\mathrm{NaOH} .{ }^{11,12}$ Reaksi pembentukan 
kristal hemokromogen dapat dilihat pada Gambar 6 berikut:

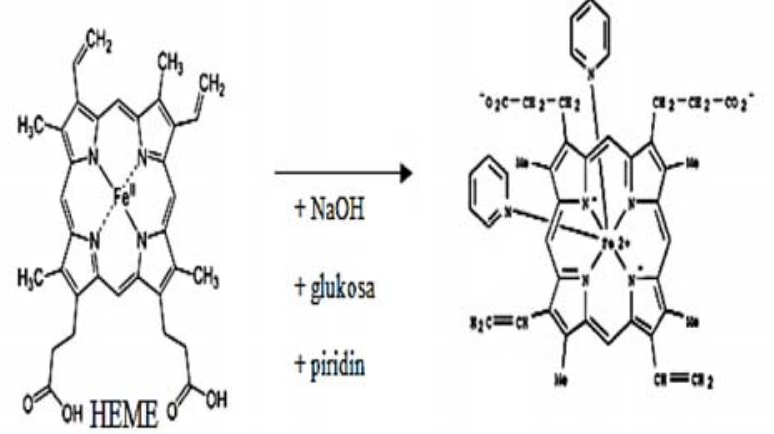

Gambar 6. Reaksi pembentukan kristal hemokromogen ${ }^{4}$

Bercak darah pada kaca objek dan kain yang dipaparkan dengan sodium hipoklorit akan menyebabkan bercak darah tidak dapat dilihat secara visual. Hal ini disebabkan oleh struktur kimia dari kaca objek dan kain yang memudahkan kerja sodium hipoklorit. ${ }^{13,14}$ Sodium hipoklorit bekerja dengan cara melepas ikatan antara Fe dan protoporfirin yang terdapat pada struktur heme. Reaksi pemecahan struktur heme dan pelepasan Fe tidak dipengaruhi oleh konsentrasi sodium hipoklorit, sesuai dengan penelitian yang dilakukan Maitra et al pada tahun 2011, sehingga kemungkinan inilah yang menyebabkan tidak dibentuknya kristal hemoglobin pada bercak darah pada kaca objek dan kain yang terpapar sodium hipoklorit. ${ }^{15}$

Penelitian yang dilakukan oleh Passi et al pada tahun 2012 mengenai bercak darah yang terpapar sodium hipoklorit dan dilakukan pemerikasaan analisis DNA menyatakan bahwa, terjadinya kerusakan pada struktur DNA yang terdapat pada bercak darah, hal ini kemungkinan disebabkan oleh sifat sodium hipoklorit sebagai oksidator kuat sehingga dapat menyebabkan kerusakan pada struktur DNA. ${ }^{16}$

\section{KESIMPULAN}

Berdasarkan hasil penelitian mengenai gambaran kristal hemoglobin pada bercak darah yang terpapar sodium hipoklorit $(\mathrm{NaOCl})$ menggunakan tes Teichmann dan tes Takayama, dapat disimpulkan bahwa tidak didapatkan gambaran kristal hemoglobin dari bercak darah pada kaca objek yang dipaparkan sodium hipoklorit konsentrasi 5,25\% dengan menggunakan tes Teichmann dan tes Takayama. Tidak didapatkan gambaran kristal hemoglobin dari bercak darah pada kaca objek yang dipaparkan sodium hipoklorit konsentrasi $0,15 \%$ dengan menggunakan tes Teichmann dan tes Takayama. Tidak didapatkan gambaran kristal hemoglobin dari bercak darah pada kain yang dipaparkan sodium hipoklorit konsentrasi 5,25\% dengan menggunakan tes Teichmann. Tidak didapatkan gambaran kristal hemoglobin dari bercak darah pada kain yang dipaparkan sodium hipoklorit konsentrasi $0,15 \%$ dengan menggunakan tes Takayama.

\section{DAFTAR PUSTAKA}

1. Maslichah S, Suryani E. Analisis pengaruh faktor internal dan eksternal penyebab timbulnya tindak kriminal dengan pendekatan simulasi sistem dinamik untuk mengurangi angka kriminalitas. Jurnal Teknik Pomits. 2012; 1(1): 1-6

2. Ja HA, Kyong JS, Wock IY, Hwan YL. Body fluid identification in forensic. BMB reports. 2012 Sep 20; 45(10): 545-53

3. Idries AM. Pedoman ilmu kedokteran forensik. Jakarta: Binarupa Aksara Publisher; 2014: 30410

4. Morgan SL, Myrick ML. Rapid visualization of biological fluids at crime scenes using optical spectroscopy. National Institute of Justice Award. 2007: 5-8.

5. Tilstone WJ, Savage KA, Clarck LA. Forensic science an encyclopedia of history, methods, and techniques. California: ABC-CLIO Inc; 2006. 90.

6. Fact Sheet Disinfection Using Chlorin Bleach.Oregon State University. 2011

7. Database terbukauntukumum: Sodium Hipoklorit. Available from: http://ik.pom.go.id/ $\begin{array}{llllllllllllll}\mathrm{v} & 2 & 0 & 1 & 3 & / & \mathrm{k} & \mathrm{a} & \mathrm{t} & \mathrm{a} & \mathrm{l} & \mathrm{o} & \mathrm{g} & /\end{array}$ NATRIUM\%20HIPOKLORIT.pdf

8. Estrela C, Estrela CRA, Barbin EL, Spano JCE, Marchesan MA, Pecora JD. Mechanism of action of sodium hypochlorite. Braz Dent J. 2002; 13 (2): 113-7 
9. James SH, Kish PE, Sutton TP. Principles of bloodstain pattern analysis: theory and practice. Taylor \& Francis Group. 2005: 361-4.

10.Gefrides L, Welch K. Forensic Biology: Serology and DNA. Springer Science+Business media, LLC. 2011; 2: 24-6

11.Stuart HJ, Paul K, Pauletten S. Principles of bloodstain analysis theory and practice and practical aspects of criminal and forensic investigation series. CRC press. 2005; 350-364

12.Casiday R, Frey R. Hemoglobin and heme group: metal complex in the blood for oxygen transport. United States: Washington University, 2007. Available from:http://www.chemistry.wustl.edu/ cedudev/LabTutorials/Hemoglobin/ MetalComplexinBlood.html
13. Kalogeras IM, Lobland HEH. The nature of the Glassy state: Structure and Glass transition. Journal of Materials Education. 2012; 34(3-4): 69-94

14.Zeronian SH. Contribution to the chemistry and Physics of cotton Fibers. AATC Review. 2015 May/June; 15(3): 36-40

15. Maitra et al. Mechanism of Hypochlorous Acid mediated Heme destruction and free iron release. NIH Public Access. 2011 April.

16.Passi N, Garg RK, Yadav M,Singh RS, Kharoshah MA. Effect of Luminol and bleaching agent on serological and DNA analysis from bloodstain. Egyptian Journal of Forensic Science. 2012; 2(2): 54-61 